\title{
Development of Ethnomathematics Teaching Materials to The Character Education Student's of Junior High School
}

\author{
Nuryadi ${ }^{1}$, Ahmad Fitriadhy ${ }^{2}$, Nafida Hetty Marhaeni ${ }^{1^{*}}$ \\ ${ }^{1}$ Mathematics Education Study Program, Faculty of Teacher Training and Education, \\ Mercu Buana University of Yogyakarta, Indonesia, ${ }^{2}$ Department of Maritime \\ Technology, Faculty of Maritime Studies and Marine Science, Universiti Malaysia \\ Terengganu, Malaysia
}

Emails: nuryadi@mercubuana-yogya.ac.id,naoe.afit@gmail.com, nafidahm@mercubuana-yogya.ac.id

\begin{abstract}
Education and culture play an important role in developing the noble values of a nation that have an impact on the formation of human character. However, the reality is that cultural values and character are increasingly eroding based on current phenomena. For this reason, it is necessary to have teaching materials that integrate character and cultural education to prevent this from being eroded. One that can bridge between culture and character-based education is ethnomathematics. For this reason, this study aims to develop teaching materials in the form of the friend app application to improve student character education through good quality puppet characters seen from the criteria of validity and practicality. This type of research is Research and Development (R\&D) which refers to the ADDIE development model (Analyze, Design, Development, Implementation, Evaluation). This research was conducted in class VIII SMP Negeri 2 Godean. In addition to students, the source of data in this study is a validator. The instruments used were the KaWan app, material expert validation questionnaire, media expert validation questionnaire and student response questionnaires. The results showed that the validity aspect was categorized as very good from the material expert and media expert validator and the practicality aspect was categorized both for small-scale trials and large-scale trials. So, KaWan apps based on character education for wayang figures to improve character education are declared suitable for use. This research will still be continued to achieve the effective criteria.
\end{abstract}

Keywords. KaWan app, Character education, ethnomathematics, wayang

\section{Introduction}

Education and culture are an inseparable unit in everyday life. This makes education and culture play an important role in developing the noble values of a nation that have an impact on the formation of human character (Wahyuni, et al., 2013). Character is a universal value that includes all human activities both in terms of relating to God, with oneself, with others or with the environment that is manifested in thoughts, feelings and behavior based on religious norms, laws, karma, culture and customs [2]. The formation of human character can be instilled from an early age based on cultural values [3]. However, in the current millennial era, the influence of modernization has made cultural values increasingly eroded. 
The erosion of cultural values can be seen based on the current phenomena. Such as rampant violence, riots, juvenile delinquency, and so on. Even other character problems still occur in Indonesia. We often hear and see from the news through electronic media such as television and radio or the internet as well as newspapers, that there are many incidents such as corruption, collusion, nepotism at all levels of jabitan, fights between students, groups of klitihan teenagers (in the city of Yogyakarta), reduced tolerance between friends or groups, drug use abuse that has spread in every level of society.

Described in the Guidebook for Internalization of Character Education in Schools (2010), teachers have a strategic position to develop the character of students in schools. This is because the teacher is a figure who can be admired and imitated or become an idol for students. Teachers can be a source of inspiration and motivation for their students. The attitude and behavior of a teacher is very imprinted on the child, so that the teacher's speech, character and personality become a mirror of the child. Thus, teachers have a great responsibility in producing a generation of character, culture, and morality. Human tasks are transformation, identification, and understanding of oneself, which must be carried out together in an organic, harmonious and dynamic unit.

The Ministry of National Education (2010) states that there are 18 values derived from religion, Pancasila, culture, and identified national educational goals, namely religious, honest, tolerance, discipline, hard work, creative, independent, democratic, curiosity, national spirit, love the homeland, appreciate achievements, friendly / communicative, love peace, love to read, care for the environment, care about social, and responsibility. The cultivation of these characters needs to be done at every level of education. However, cultivating character values is a difficult thing so efforts are needed to bridge the gap between character education and culture in Indonesia.

One that can bridge between culture and character-based education is ethnomathematics. Ethnomathematics is a form of mathematics that is influenced or based on culture. Ethnomathematics was introduced by D'Ambrosio, a Brazilian mathematician in 1977. According to D'Ambrosio ethnomathematics is the study of mathematics that takes into account the cultural considerations in which mathematics emerges by understanding the mathematical reasoning and systems they use [4]. The study of ethnomathematics in learning mathematics covers all fields: architecture, weaving, sewing, agriculture, kinship, ornament, and spiritual and religious practices are often in harmony with patterns that occur in nature or ordered systems of abstract ideas is of the view that at present the field of ethnomathematics, namely mathematics that arises and develops in society and in accordance with local culture, is the center of the learning process and teaching method [5].

Through the application of ethnomathematics in education, especially mathematics education, it is hoped that later students will be able to better understand mathematics, and better understand their culture, and later it will be easier for educators to instill cultural values themselves in students, so that cultural values which are part of the nation's character are embedded since early in the students. Character education is also closely related to school management or management. The management in question is how character education is planned, implemented, and adequately controlled in educational activities. Character education in the city of Yogyakarta is one of the effective media in schools in instilling good values. The dimension of character education includes its relationship with God, its relationship with oneself, its relationship with others, its relationship with the environment [6].

For this reason, the research carried out intends to produce ethnomathematical teaching materials based on character education through culture in Indonesia, namely wayang figures. 
There are previous studies, namely the Development of Multicultural-Based Character Education Models and local wisdom for early childhood in the Central Java Province, including: Prayitno (2004) research on character and education can be done through: (a) outlining the education calendar, (b) compiling a schedule lessons and division of teaching tasks, (c) regulate the implementation of the preparation of semester teaching programs and lesson preparation, (d) regulate the implementation of the preparation of curricular and extracurricular programs, (e) regulate the implementation of assessments, (f) regulate the implementation of grade promotions, (g) make reports learning progress of students, (h) managing efforts to improve and enrich teaching [7]. Ahmad's research (2001) formulates the value of character as a conception of what is desired, which influences the choice of means, intermediate goals and ultimate goals of action [8]. Research by Nadraha (2007) there are several academic approaches to character value education that can be further elaborated in order to develop education based on character and cultural values: (1) cognitive development approach; (2) value analysis approach; (3) value clarification approach; (4) approach to learning to do [9]. Steger's research results (2006) character education is not limited to the transfer of knowledge about good values an-sich, but reaches out to how to make these values embedded and integrated in the totality of thought-action [10]. Sue Stubbes (2002) in Education for Character: How Our School Can Teach Respect and Responsibilty states that character building includes the following three things: knowing the good, wanting to do good (desiring the good) and encouraging them to do good actions (doing the good) [11].

\section{Method}

This type of research is research development or Research and Development (R\&D) using the ADDIE development model (Analyze, Define, Design, Development, Implementation, Evaluation). In this study, the product produced is teaching materials in the form of the Kawan App application with ethnomathematics with a character education approach. This application development research procedure contains research and development steps using the ADDIE model which in its development stage is also carried out product feasibility testing, limited to validity and practicality. The selection of the ADDIE model was based on the consideration that the model development was carried out systematically. The procedures for this research are as follows:

\subsection{Analyze Phase}

This stage was carried out to see a description of the conditions in the field related to the teaching and learning process of Determinant and Inverse Matrix Materials at SMA Negeri 1 Imogiri, Yogyakarta and then analyzed the problem. The process carried out is an analysis of the competencies that must be achieved by students, material analysis, and an analysis of the characteristics of students

\subsection{Design Phase}

At the design stage, the researcher designs the product according to the results of the analysis that has been done. The purpose of this stage is to design the product to be developed.

\subsection{Development Phase}

This stage is carried out by writing an application draft, developing an assessment instrument, student response questionnaires, application validation and application revision. 


\subsection{Implementation Phase}

At this stage, the products produced in the development stage are implemented in real situations, namely classes.

\subsection{Evaluation Phase}

Evaluation occurs in each of the four stages above. At this stage the researcher has not carried out any evaluation activities on the quality of the product developed by the device.

Nieveen says that product quality, design, development, and evaluation of programs must meet the criteria of being valid, practical, and effective [12]. According to Nieveen the quality of the product is said to be valid in terms of its relation to the purpose of product development itself must be really considered. Valid teaching materials are teaching materials that get an average value from expert assessments in the "good" category [13]. Nieveen says that practicality is seen from the opinions of users, especially teachers and students who consider the resulting product easy to use and also describes the actual learning process. Teaching materials are said to be practical if the student's response is at least in the "good" criteria [14].

\section{Result and Discussion}

This research was conducted using the ADDIE model in development research. Kawan-app, which was developed based on watang character education, was used to help improve the character of students in flat wakes. The developed application has gone through several stages to obtain valid and practical criteria. The ADDIE model is divided into 5 stages, namely analysis, design, development, implementation and evaluation. In the initial stage, namely analysis, researchers analyze the needs in schools as a reference for developing products. Needs analysis includes competency analysis that must be achieved by students, material analysis, and analysis of student characteristics as follows:

1. The analysis of competencies that must be achieved by students has been adjusted to the Core Competencies (KI) and Basic Competencies (KD) which have been stipulated in Permendikbud No 37 of 2018.

2. The material used in the application is a flat shape that is attached to the puppet. This means that each wayang is analyzed ethnomatically in the form of what shapes are in each wayang character.

3. Characteristics of students consistently show that students need friend teaching materials that can improve student character education.

Next, the researcher carried out the product design stage. At this stage the researcher designed the kawan -app according to the needs analysis. Kawan-app is designed based on the facts on the ground that students need an application that makes problems as a starting point and can analyze student character education. At this stage, the researcher makes a concept map of the presentation of the application, determines the format of the application, and makes the stages of learning in character education-based applications. The next stage is development, the researcher develops the product as a whole, namely completing the kawan apps that have components, namely ethnomathematics worksheets and character education. The application design can be seen in Figure 1-3.

After completing the character education-based math app, the researchers validated the material experts and media experts to see the validity of the developed product. Completion of the kawan -app went through several revisions. The results of validator 1 which are described in the subsection of research results are the average scores obtained, while for validator 2 it is 


\section{Technium Sustainability}

Technium Sustainability

Vol. 2, No. 1, pp.31-37 (2021)

ISSN: 2810-2991

www.techniumscience.com

done once. The things above have been revised, then the researcher tested the validity back to validator 1 and obtained valid results. This is because based on the assessment of the material expert, the average score of 78 in the good category and the assessment of the media expert obtained a score of 75 in the good category.

The step taken after the product developed is declared valid is implementation. At this stage, the app that has been declared valid is implemented directly for students. Implementation was carried out twice, namely small-scale trials and then large-scale trials. In a small-scale trial, 6 students of class VII were taken to use the kawan -app that had been developed and then filled out student response questionnaires that had been reviewed by experts. The subjects of the small-scale trial were chosen by 2 people with low abilities, 2 people with moderate abilities, and 2 people with high abilities. The results of the small-scale student response questionnaire show the kawan -app developed is very good, with these results the friend-app developed has been declared practical.
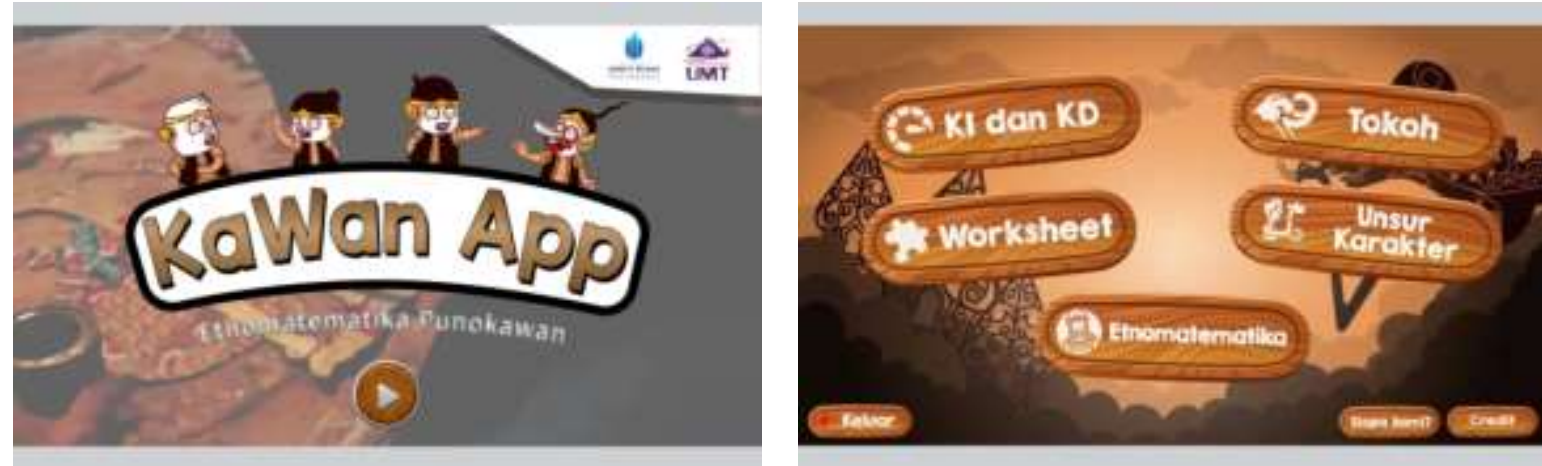

Figure 1. Landing and Menu Kawan App
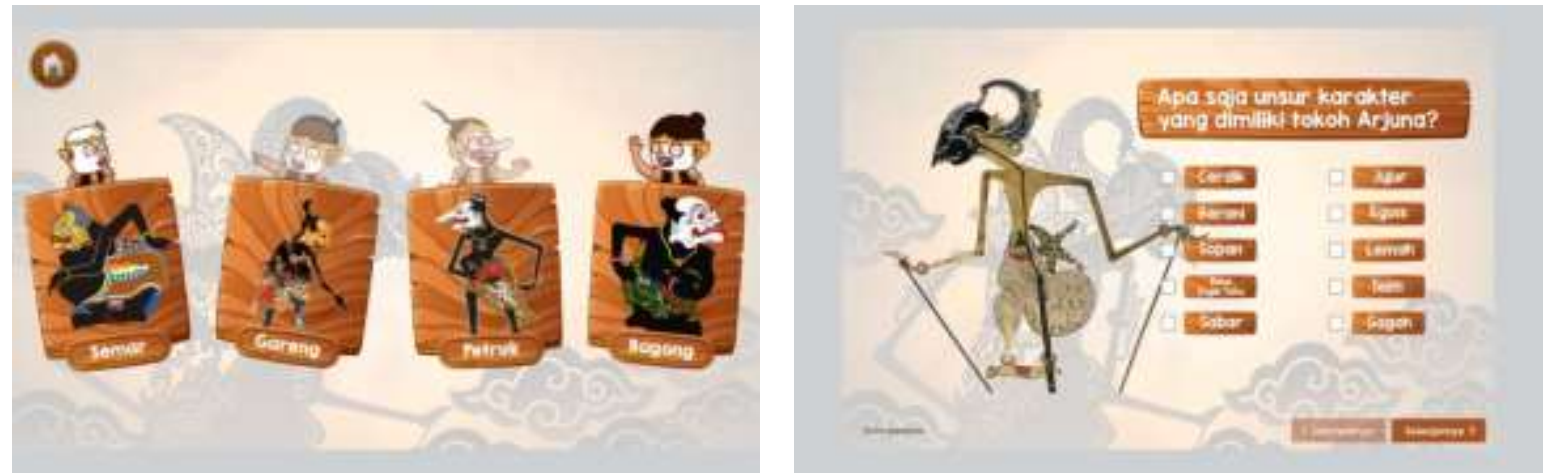

Figure 2. Character Wayang and Worksheet Character Education
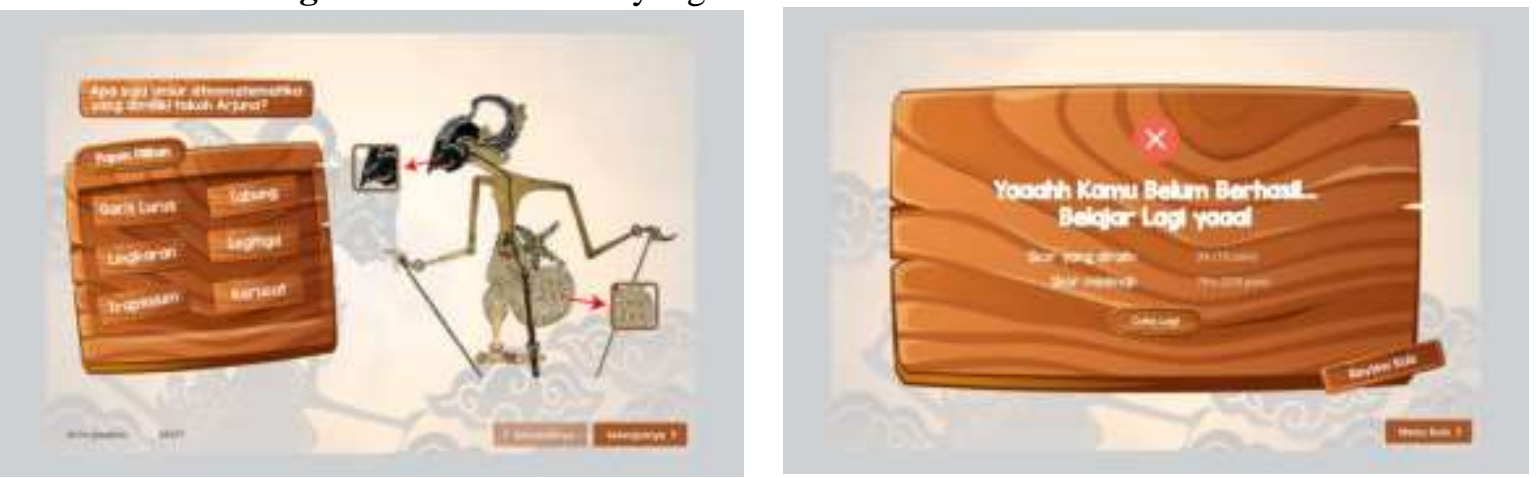

Figure 3. Worksheet Ethnomathematics and Scorring 
Practical trials were continued on a large scale, namely in class VIIIB which is the experimental class. This class is given treatment by learning using the kawan-app. After students learn using the kawan -App, students also provide an assessment of the kawan-app by filling out student response questionnaires. The number of students in the experimental class who used the friend-app was 31. In large-scale trials obtained an average score of 59 with good categories and the results obtained showed that all students stated that the kawan -app was practically used.

\section{Conclusion}

Based on the explanation in the previous chapter, it can be concluded that the development of an ethnomathematical-based friend app to improve character education is carried out using the ADDIE model (Analyze, Design, Development, Implementation, Evaluation) which contains 18 character education and ethnomathematics on flat-shaped materials. Then the ethnomathematics-based app to improve character education meets the valid criteria. This is because based on the assessment of the material expert, the average score of 78 in the good category and the assessment of the media expert obtained a score of 75 in the good category. The ethnomathematical-based Kawan-app to improve the character education of students meets practical criteria based on the assessment of student response questionnaires from both small-scale trial classes and large-scale trials. In large-scale trials obtained an average score of 59 with good categories. This research will still be continued at the evaluation stage to determine the effectiveness of the developed product.

\section{References}

[1]. Wahyuni, A., Tias, A. A. W., \& Sani, B. (2013, November). Peran etnomatematika dalam membangun karakter bangsa. In Makalah Seminar Nasional Matematika dan Pendidikan Matematika, Prosiding, Jurusan Pendidikan Matematika FMIPA UNY, Yogyakarta: UNY.

[2]. Zuhdi, D. 2013.Model Pendidikan Karakter:Terintegrasi dalam Pembelajaran dan Pengembangan Kultur Sekolah. Yogyakarta: Multi Presindo.

[3]. Panjaitan, A. P., Darmawan, A., Purba, I. R., Rachmad, Y., \& Simanjuntak, R. (2014). Korelasi Kebudayaan dan Pendidikan: Membangun Pendidikan Berbasis Budaya Lokal. Yayasan Pustaka Obor Indonesia.

[4]. D'Ambrosio, U. (1985). Ethnomathematics and its place in the history and pedagogy of mathematics. For the Learning of Mathematics, 5(1), 44-48.

[5]. Shirley, L. 1995. Using Ethnomathematics to find Multicultural Mathematical Connection: NCTM.

[6]. Harun, Jaedun, A., Sudaryanti, Manaf, A. 2020. Pendidikan Karakter Anak Usia Dini dalam Dimensi Berketuhanan. Jurnal Kependidikan, 4(2), 357-368.

[7]. Prayitno. 2004. Budi pekerti dan pendidikan. Kertas kerja seminar moral, pendidikan, pendidikan budi pekerti, anjuran Pusat Kurikulum dan Sarana Pendidikan, Balitbang Dikbud, 2-3 Ogos 1994.

[8]. Ahmad, M.S. 2001. Filsafat etika: Tanggapan kaum rasionalis dan intuisionalis. Jakarta: Serambi.

[9]. Nadraha, T. 2007. Mengartikulasikan pendidikan nilai, budaya organisasi. Jakarta: Rineka Cipta. 
[10]. Steger, M.B. 2006. Globalisme bangkitnya ideologi pasar. Yogyakarta: Lafadly Pustaka.

[11]. Sue Stubbs. 2002. Inclusive education where there are few resources. IDP Norway. The Atlas Alliance Globa Support to Disabled People.

[12]. Nieveen. (1999). Prototyping to Reach Product Quality. Dalam Van Den Akker, J., Branch, R.M., Gustafson, K., Nieveen, N., \& Plomp, T. (Eds). Design Upproaches and Tool in Education and Training (125-135).

[13]. Fatmasuci, F.W. (2017). Pengembangan PerangkatPembelajaran Berbasis Masalah Berorientasi Pada Kemampuan Komunikasi dan Prestasi Belajar Matematika Siswa SMP. Jurnal Riset Pendidikan Matematika, 4(1), 32-42.

[14]. Hamimi, L., Ikhsan, M., \& Abidin, Z. (2018). Pengembangan Perangkat Pembelajran Pembuktian Menggunakan Model Pembelajaran Guided Inquiry Untuk Meningkatkan Kemampuan Geometri Siswa Sekolah Menengah Atas. Jurnal Didaktik Matematika, 5(1), 16-26. 